Check for updates

Cite this: RSC Adv., 2018, 8, 33817

Received 14th July 2018

Accepted 12th September 2018

DOI: $10.1039 / \mathrm{c} 8 \mathrm{ra05997g}$

rsc.li/rsc-advances

\section{Ash deposition behavior of a high-alkali coal in circulating fluidized bed combustion at different bed temperatures and the effect of kaolin}

\begin{abstract}
Yanquan Liu, (D) Leming Cheng, (D) * Jieqiang Ji, Qinhui Wang and Mengxiang Fang (iD
High alkali and alkali earth metals (AAEMs) content in coal causes severe slagging and fouling during combustion in a boiler. In this study, the ash deposition behavior of a high-alkali coal at different bed temperatures and the effect of kaolin were investigated in a $30 \mathrm{~kW}$ circulating fluidized bed (CFB) test system using an ash slagging probe and deposition probe. The results show that the ash deposition tendency increases with the bed temperature. The condensation of $\mathrm{Na}_{2} \mathrm{SO}_{4}$ is an important inducement for slag formation in the furnace. The melting or partial melting of slags is attributed to $\mathrm{Na}-\mathrm{Fe}-\mathrm{Ca}$ eutectics. At $920{ }^{\circ} \mathrm{C}, \mathrm{Na}_{2} \mathrm{SO}_{4}$ will react with $\mathrm{CaSO}_{4}$ to form the low-melting compound of $\mathrm{Na}_{2} \mathrm{SO}_{4}-$ $\mathrm{CaSO}_{4}$. The deposited ash on the convection-heating surface consists of granular particles. On the windward side, the layered-structure ash deposits, i.e. the inner and outer layers, are formed at the bed temperature of $920^{\circ} \mathrm{C}$ but are absent at lower temperatures $\left(820^{\circ} \mathrm{C}\right.$ and $870{ }^{\circ} \mathrm{C}$ ). The formation of the inner layer consists of fine particles $(<2 \mu \mathrm{m})$ and is closely related to $\mathrm{Na}_{2} \mathrm{SO}_{4}$. The size of the deposited ash in the outer layer is larger than $10 \mu \mathrm{m}$, while that on the leeward side is less than $10 \mu \mathrm{m}$. By adding kaolin in the coal, the slags are replaced by loose particles due to the absorption reactions between kaolin and alkali metals. The ash deposition tendency is improved and the optimal result is achieved when kaolin is added at an addition ratio of $3 \%$.
\end{abstract}

\section{Introduction}

The high contents of alkali and alkali earth metals (AAEMs) in coal may induce severe slagging and fouling during combustion in a boiler. Zhundong (ZD) coal with an estimated amount of $390 \mathrm{Gt}$, mined in Xinjiang Province, China, is a typical coal with high-alkali content. It has the characteristics of low-ash, lowsulfur, and high-volatile contents, and has an excellent combustibility. Unfortunately, several ash-related issues, including slagging and fouling, frequently occur in boilers. ${ }^{1,2}$ These issues will worsen heat transfer, corrode tubes, and even lead to unscheduled shut-downs of boilers.

To date, many research studies have been conducted to understand the ash deposition mechanism of high-alkali coals. In a pulverized-coal (PC) boiler, the slagging on the water-cooled wall was mainly induced by the low-temperature eutectics from the reaction of $\mathrm{CaO}$ and $\mathrm{Fe}_{2} \mathrm{O}_{3}$ on the receding char surface, and the eutectic Ca-Al-Si-containing $\mathrm{Fe}^{2+}$-bearing oxide. ${ }^{3}$ Wei et al. ${ }^{2}$ reported that the slagging deteriorated from the bottom to the top on the water wall and that the slags had an obvious layer structure only at the platen superheater, where the gas temperature was approximately $1000{ }^{\circ} \mathrm{C}$. The condensed $\mathrm{CaSO}_{4}$

State Key Laboratory of Clean Energy Utilization, Institute for Thermal Power Engineering, Zhejiang University, Hangzhou 310027, P. R. China. E-mail: lemingc@ zju.edu.cn was the main compound in the inner layer and few fused particles with high Na content played key bonding roles during ZD coal combustion. Zhou et al. ${ }^{4}$ reported that gaseous $\mathrm{NaCl}$ could react with silicates or aluminosilicates to form alkali-rich silicates or aluminosilicates, which could impact and adhere to the deposited surface due to their low-melting temperature. In the convection region, AAEMs also played important roles in ash deposition..$^{5,6}$ These inorganic vapors deposited on the heating surface and fly ash particles via condensation, thermophoresis and chemical reactions. ${ }^{7-9}$ For instance, Li et al. ${ }^{10}$ systematically investigated the characteristics of ash deposits formed on an air-cooled steel probe simulating superheater surfaces at different temperatures. They reported that fine ash rich in $\mathrm{Na}, \mathrm{Ca}, \mathrm{S}$, and $\mathrm{Mg}$ on the probe was responsible for the severe ash deposition. Additionally, deposited Na species could act as an adhesion agent to aggravate ash deposition. ${ }^{11}$

As discussed above, the volatilization and deposition of AAEMs were important for the ash deposition of high-alkali coals. Therein, the volatilization of AAEMs was greatly influenced by the reaction temperature, and higher temperatures would lead to an increased amount of AAEMs vaporized into the flue gas. ${ }^{12,13}$ Lowering the reaction temperature may be a strategy to alleviate the ash deposition tendency. Therefore, the circulated fluidized bed (CFB) with a relatively low-reaction temperature $\left(850-950{ }^{\circ} \mathrm{C}\right)$, was considered as a promising technology to utilize ZD coal. 
Previous investigations on the utilization of other high-alkali fuels in CFB boilers, such as biomass, ${ }^{14}$ coal/biomass blend, ${ }^{15}$ and Victorian coal, ${ }^{\mathbf{1 6}}$ provided valuable information. However, the process was still a major challenge because of the diversity of fuels. Song et al. ${ }^{17,18}$ carried out extensive work on the utilization of $\mathrm{ZD}$ coal in a CFB. The results showed that reaction temperature, reaction atmosphere and coal properties had considerable influences on the ash deposition characteristics. The degree of slagging in the furnace increased as a function of the reaction temperature during gasification. ${ }^{17}$ Under combustion conditions, the fouling on heating surfaces at medium temperatures $\left(607-735{ }^{\circ} \mathrm{C}\right)$ was the main ash-related problem. ${ }^{18}$ However, the influence of the combustion temperature on fouling is not clear. Furthermore, the formation mechanism of slags in the furnace is rarely reported during ZD coal combustion. Thus, the ash deposition behavior of $\mathrm{ZD}$ coal should be further studied at different temperatures in a CFB.

In addition, the additive injection technology is an alternative to solve or mitigate ash deposition problems of highalkali coals given the problems associated with the burning of $100 \%$ ZD coal in boilers. Kyi et al. ${ }^{19}$ screened appropriate additives from twelve minerals for preventing fouling during Victorian brown coal combustion. The kaolin mineral was considered to be one of the best candidates to absorb $\mathrm{Na}$ compounds. $\mathrm{Xu}$ et al. ${ }^{\mathbf{2 0 , 2 1}}$ investigated the alkali capture mechanism of kaolin. The addition of kaolin could lead to the increased deposition of $\mathrm{Na}$ onto the ash when high-alkali coal was fired in the laboratory drop tube furnace. The effectiveness of alkali capture was influenced by the kaolin dosage, combustion temperature and particle sizes. In addition, kaolin can improve the ash fusion/sintering characteristics by altering the ash composition. Wei et al. ${ }^{22}$ recommended that the blending amount of kaolin should be as high as $9 \%$ to ensure that the ash fusion temperatures were higher than those for raw coal in the PC furnaces during the burning of ZD coal. Moreover, the optimum temperature for enhancing the capacity of sodium capture was approximately $1000{ }^{\circ} \mathrm{C}$. However, the practical results from the ash deposition were not reported after adding kaolin into ZD coal in a CFB. It is, therefore, necessary to evaluate the effect of kaolin in avoiding the severe ash deposition problem.

This study reports the ash deposition behavior during the burning of high-alkali $\mathrm{ZD}$ coal at different bed temperatures $\left(820{ }^{\circ} \mathrm{C}, 870{ }^{\circ} \mathrm{C}\right.$ and $920{ }^{\circ} \mathrm{C}$ ) in a $30 \mathrm{~kW}$ CFB test system. According to the characterization of fly ash and ash deposits, the ash deposition mechanisms in the furnace and convection region are analyzed. In addition, the effect of kaolin on the mitigation of ash deposition are evaluated to expand the utilization of ZD coal.

\section{Experimental}

\subsection{Zhundong coal}

Tables 1 and 2 present the results of proximate, ultimate and ash composition analysis of Zhundong (ZD) coal, which were determined according to the coal analysis standards in China, including GB/T212-2008, GB/T213-2008, GB/T476-2008, and GB/
T1574-2007, etc. Based on the ash composition, the ash deposition tendency of ZD coal can be evaluated by slagging/fouling indices. Specifically, the base/acid ratio $\left(\mathrm{B} / \mathrm{A}=\left(\mathrm{Fe}_{2} \mathrm{O}_{3}+\mathrm{CaO}+\right.\right.$ $\left.\left.\mathrm{MgO}+\mathrm{Na}_{2} \mathrm{O}+\mathrm{K}_{2} \mathrm{O}\right) /\left(\mathrm{SiO}_{2}+\mathrm{Al}_{2} \mathrm{O}_{3}\right)\right)$ and fouling index $(f=\mathrm{B} / \mathrm{A} \times$ $\mathrm{Na}_{2} \mathrm{O}$ ) are commonly used. ${ }^{23}$ The calculated values of these indices are 0.6 and 2.1 for $\mathrm{ZD}$ coal, respectively. This indicates that ZD coal has a medium slagging tendency and a severe fouling tendency according to the evaluation criterion. ${ }^{24}$ Before the tests, the coal samples were ground and sieved to sizes in the range of $0-2 \mathrm{~mm}$.

\subsection{Kaolin}

Kaolin, a chemically pure standard material with a Sauter mean diameter of $7.4 \mu \mathrm{m}$, was used as an additive to evaluate the effects on ash deposition when ZD coal was combusted in a CFB test system. Its chemical composition is given in Table 3. The kaolin was well mixed with ZD coal at the addition ratios of $3 \%$ and $6 \%$ based on mass.

\subsection{Experimental system}

Ash deposition tests were conducted in a $30 \mathrm{~kW}$ CFB test system, as shown in Fig. 1. The CFB furnace is $4.8 \mathrm{~m}$ high with an inner diameter of $200 \mathrm{~mm}$ in the upper sections. Thermocouples and pressure sensors are equipped to measure the temperatures and pressures along the furnace. After exhausting from the cyclone, the flue gas passes in turn through the gas cooler, bag filter, and fan.

To start up the CFB system, silica sand was added to the furnace and loop seal as the bed material. It was sieved in the size range of 0-3 mm, and its average diameter was $1.1 \mathrm{~mm}$. Air was introduced into the furnace by a fan through the air distribution plate at the bottom of the furnace. The bed material was heated by heating wires until its temperature reached $550{ }^{\circ} \mathrm{C}$. At the same time, the fuel was fed into the furnace with a screw feeder, leading to further increase in the temperature. When the bed temperature increased to the designated value, the circulation air entered to construct the circulation combustion. Finally, the relative operation parameters were carefully regulated to achieve the stable operation of the CFB system.

In the $\mathrm{ZD}$ coal burning tests, the bed temperature was kept at $820^{\circ} \mathrm{C}, 870{ }^{\circ} \mathrm{C}$, and $920^{\circ} \mathrm{C}$, while for the kaolin effect tests this temperature was $920{ }^{\circ} \mathrm{C}$. The fluctuation range of the temperature was controlled at $\pm 10{ }^{\circ} \mathrm{C}$. The $\mathrm{O}_{2}$ concentration in the flue gas was measured by a ZrO oxygen analyzer. Each test lasted for $4 \mathrm{~h}$. The detailed operation parameters are listed in Table 4.

\subsection{Sampling probes and analysis}

To investigate the ash slagging and deposition behavior on heating surfaces, an ash slagging probe and an ash deposition probe were designed. The slagging probe was placed in the upper part of the CFB furnace, while the ash deposition probe was installed in the convection backpass between the cyclone and gas cooler (shown in Fig. 1).

Fig. 2 shows the schematics of the two probes made of jacket tubes of stainless steel. Their surface temperatures can be 
Table 1 Proximate and ultimate analysis of Zhundong coal (ad: air dry basis; ar: received basis)

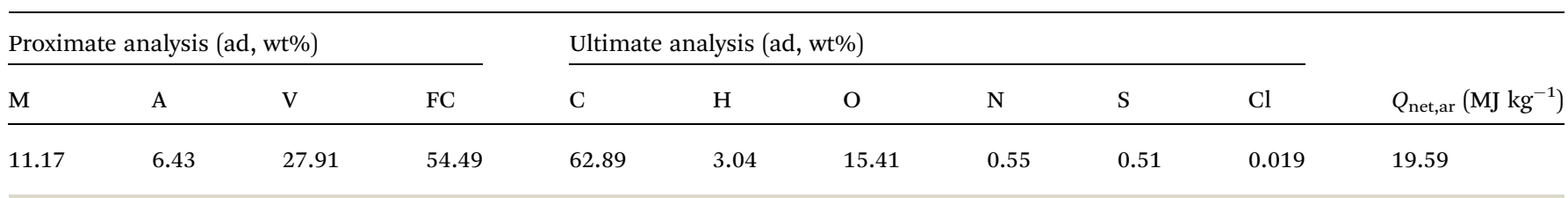

Table 2 Ash composition analysis of Zhundong coal (wt\%)

\begin{tabular}{lllllllll}
\hline $\mathrm{SiO}_{2}$ & $\mathrm{Al}_{2} \mathrm{O}_{3}$ & $\mathrm{Fe}_{2} \mathrm{O}_{3}$ & $\mathrm{CaO}$ & $\mathrm{MgO}$ & $\mathrm{K}_{2} \mathrm{O}$ & $\mathrm{Na}_{2} \mathrm{O}$ & $\mathrm{TiO}_{2}$ & $\mathrm{SO}_{3}$ \\
\hline 41.57 & 11.16 & 4.79 & 16.21 & 6.48 & 0.51 & 3.50 & 0.39 & 8.05
\end{tabular}

Table 3 Chemical composition of kaolin (wt\%)

\begin{tabular}{lcccccccc}
\hline $\mathrm{SiO}_{2}$ & $\mathrm{Al}_{2} \mathrm{O}_{3}$ & $\mathrm{Fe}_{2} \mathrm{O}_{3}$ & $\mathrm{CaO}$ & $\mathrm{MgO}$ & $\mathrm{K}_{2} \mathrm{O}$ & $\mathrm{Na}_{2} \mathrm{O}$ & $\mathrm{TiO}_{2}$ & $\mathrm{SO}_{3}$ \\
\hline 48.46 & 47.70 & 0.35 & 0.30 & 0.29 & 0.14 & 0.26 & 1.54 & 0.028
\end{tabular}

controlled by air flowing inside the tube. Because the aerodynamic conditions in the furnace and convection region of the backpass are not the same due to their different flow crosssections, the outer diameters of the slagging and ash deposition probes were respectively designed according to similar Stokes number principles in industrial CFB boilers. ${ }^{25}$ Thus, there are a few differences in the structures of the two probes. The outer diameter of the slagging probe was $30 \mathrm{~mm}$; a thermocouple was installed at the posterior surface of the probe to measure its surface temperature. The ash deposition probe was sealed by a probe with an outer diameter of $40 \mathrm{~mm}$ on the top of the outer tube. A thermocouple was inserted into the probe on the windward and was closely adjacent to the probe surface. During the tests, the surface temperatures of the two probes were controlled at approximately $400{ }^{\circ} \mathrm{C}$. The gas temperature around the slagging probe was calculated by the average of $T_{6}$ and $T_{7}$, while the corresponding temperature around the ash deposition probe was determined by $T_{10}$.

The ash collection efficiency ( $\zeta)$ was used to evaluate the ash deposition tendency. It is defined as the mass ratio of the

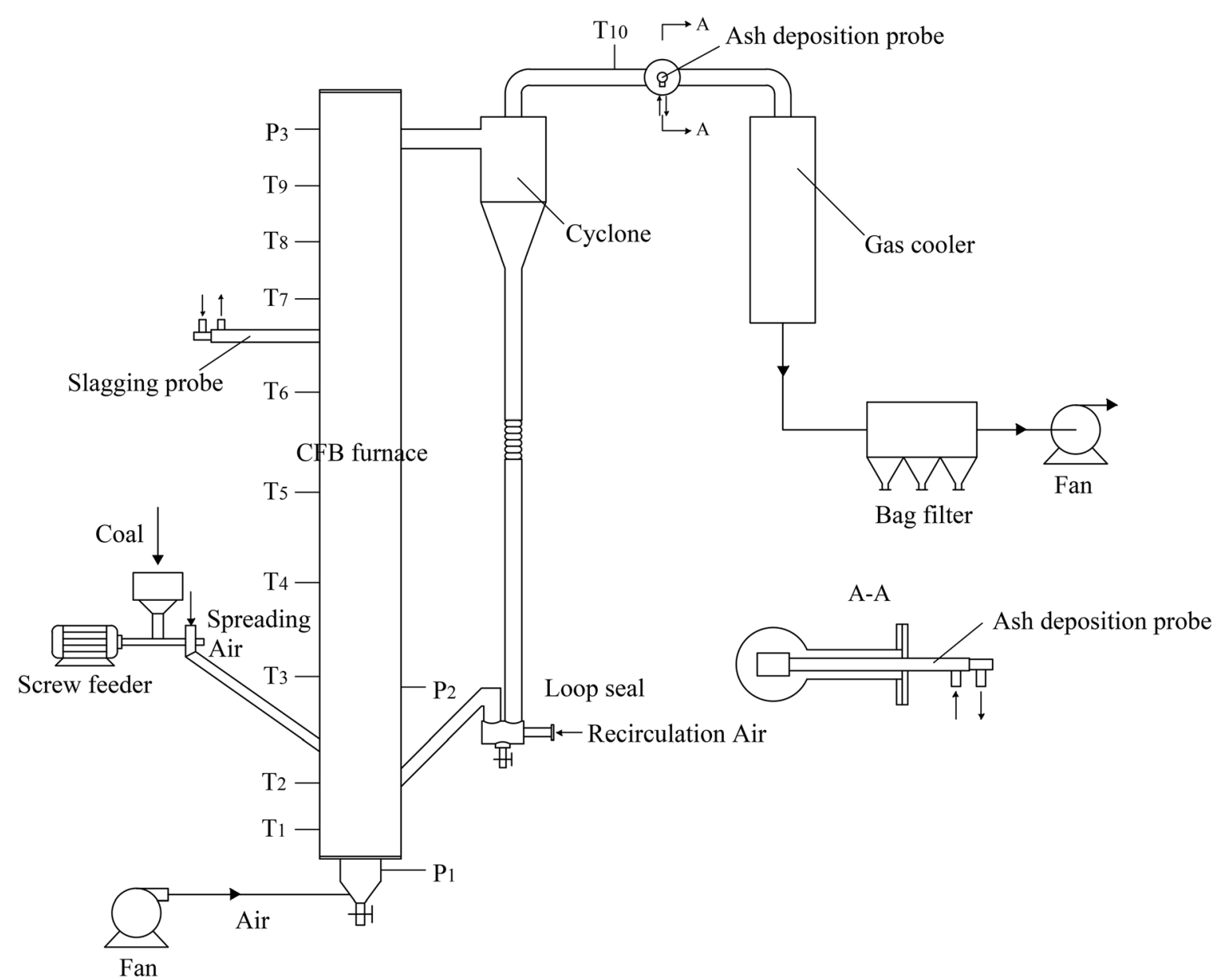

Fig. 1 Schematic of a 30 kW CFB test system. 
Table 4 Operating parameters for each of the conducted tests

\begin{tabular}{llllll}
\hline Test & I & II & III & IV & V \\
Bed temperature $\left({ }^{\circ} \mathrm{C}\right)$ & 820 & 870 & 920 & 920 & 920 \\
Coal feeding rate $\left(\mathrm{kg} \mathrm{h}^{-1}\right)$ & 6.57 & 7.04 & 7.46 & 8.17 & 8.63 \\
O $_{2}$ concentration in flue gas $(\%)$ & 6.7 & 6.3 & 5.9 & 5.6 & 5.1 \\
Addition ratio of kaolin $(\%)$ & 0 & 0 & 0 & 3 & 6
\end{tabular}

deposited ash particles over the fly ash particles entrained into the projected area of the probe coupon. ${ }^{11}$ The collection efficiency excluded the effect of ash concentration on the ash deposition flux, and thus facilitated the comparison of the ash deposition tendencies.

$$
\zeta=\frac{m_{\mathrm{d}}}{m_{\mathrm{F}} Y_{\mathrm{ash}} a_{\mathrm{fh}}} \frac{A_{\mathrm{c}}}{A_{\mathrm{p}}} \times 100 \%
$$

where $m_{\mathrm{d}}$ is the mass of ash deposits, kg; $A_{\mathrm{c}}$ is the crosssectional area of the convection flue gas pass, $\mathrm{m}^{2} ; m_{\mathrm{F}}$ is the total mass of feeding coal, $\mathrm{kg} ; Y_{\text {ash }}$ is the mass fraction of ash in the coal, $\% ; \alpha_{\mathrm{fh}}$ is the ratio of fly ash, $\% ; A_{\mathrm{p}}$ is the projected area of the sampling probe, $\mathrm{m}^{2}$.

At the end of each test, the fly ash was collected from the bag filter. To burn out the residual carbon, the fly ash samples were ashed at $575{ }^{\circ} \mathrm{C}$ according to ASTM standard E1755-01 before the analysis. ${ }^{26}$ The different ash deposits were carefully collected from the slagging and ash deposition probes. The bulk chemical compositions of fly ash and ash deposits were analyzed by X-ray fluorescence (XRF, HD Prime Analyzer). The mineral analysis of these samples was performed by X-ray diffraction (XRD, X'pert Pro) to identify the mineral composition. Additionally, the micro-morphologies of ash deposits were obtained by scanning electron microscopy (SEM, SIRION100).

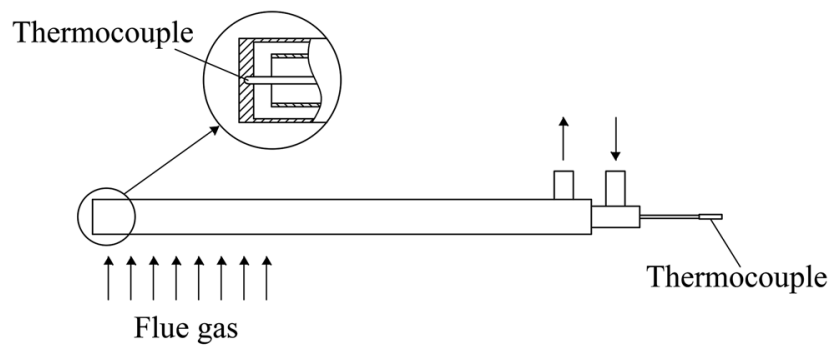

(a) Slagging probe

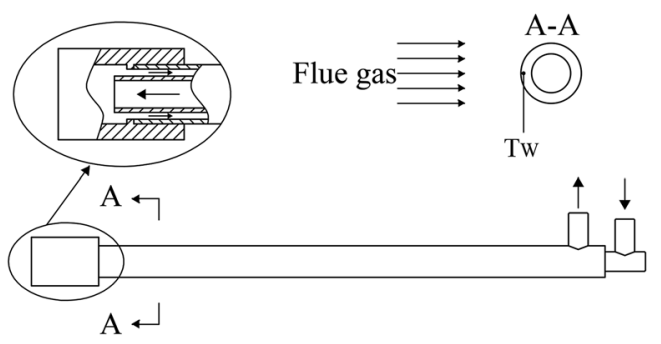

(b) Ash deposition probe

Fig. 2 Schematics of the slagging probe and ash deposition probe.

\section{Results and discussion}

\subsection{Ash deposition behavior in the furnace}

3.1.1 Slag morphologies. The bed temperatures were stably operated at $820^{\circ} \mathrm{C}, 870{ }^{\circ} \mathrm{C}$, and $920{ }^{\circ} \mathrm{C}$, during the tests. Fig. 3 presents the temperature profiles along the bed height. In the tests, the highest temperature region in the furnace was located between $T_{4}-T_{6}$. Their average values were $894{ }^{\circ} \mathrm{C}, 929{ }^{\circ} \mathrm{C}$, and $972{ }^{\circ} \mathrm{C}$ at three different bed temperatures, respectively. The temperature of flue gas where the slagging probe was located ranged between $865-913{ }^{\circ} \mathrm{C}$. The temperature range of the ash deposition probe was $653-681{ }^{\circ} \mathrm{C}$. By adding kaolin, the temperatures at $T_{3}-T_{10}$ became slightly higher compared to those for the test of $\mathrm{ZD}$ coal at $920^{\circ} \mathrm{C}$. The highest temperatures in the furnace were approximately $975{ }^{\circ} \mathrm{C}$ and $985{ }^{\circ} \mathrm{C}$ for $3 \%$ kaolin and $6 \%$ kaolin, respectively. This is related to the increasing content of ash in the flue gas after the addition of kaolin. The fly ash particles increase the thermal capacity of flue gas during combustion.

The macro-morphologies of ash deposits formed on the slagging probe are almost the same at different bed temperatures, as shown in Fig. 4(a). The ash deposits, referred to as slags, constitute a compacted ash layer that tightly adheres to the entire metal surface. This indicates that the slags have sintered, shrunken, or melted at relatively high temperatures, and there were strong adhesion forces between the slags and metal surfaces; it was difficult to clean-up/remove the slags using conventional soot blowers. Fig. 4(b) presents the variation trend of the collection efficiency as a function of the bed temperature. Higher temperatures lead to more slags being formed. Moreover, the slags have a reddish color, suggesting the presence of iron oxides.

3.1.2 Chemical compositions of slags and fly ash. Fig. 5 shows the bulk chemical compositions of slags and fly ash at different bed temperatures. The contents of $\mathrm{Na}_{2} \mathrm{O}, \mathrm{K}_{2} \mathrm{O}, \mathrm{Fe}_{2} \mathrm{O}_{3}$, and $\mathrm{SO}_{3}$, in the slags are obviously higher, compared to those in the fly ash. Moreover, their contents in the slags increase with the temperature, while those in the fly ash decrease. It was

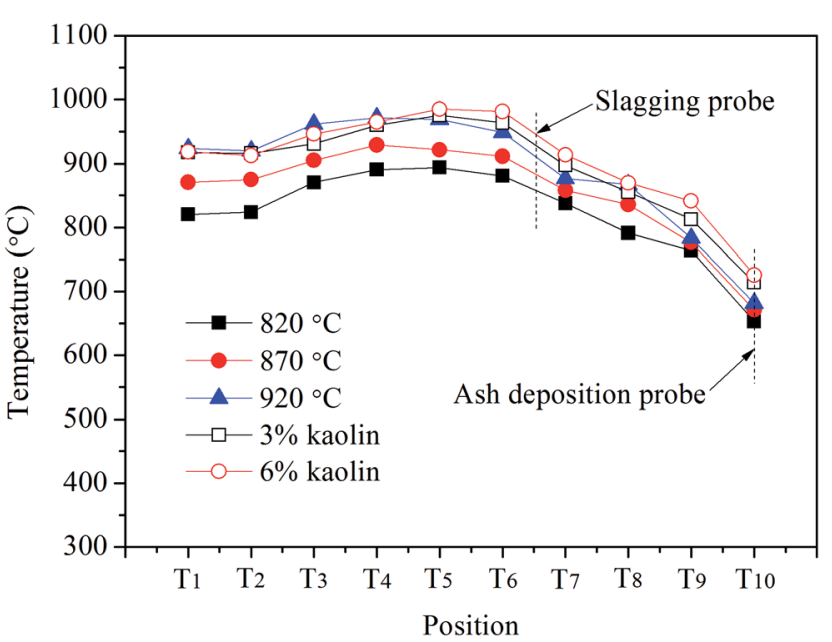

Fig. 3 Temperature profiles of flue gas along the furnace. 
(3) $\mathrm{T}_{\text {bed }}=920^{\circ} \mathrm{C}$

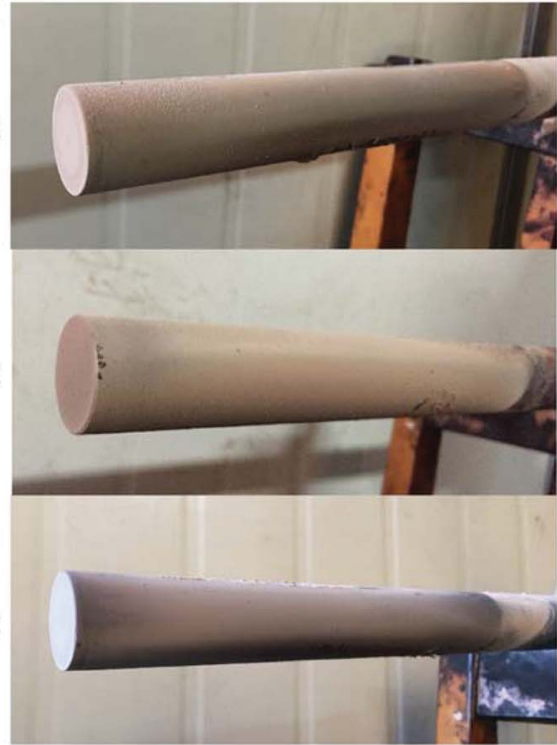

(a) Macro-morphology

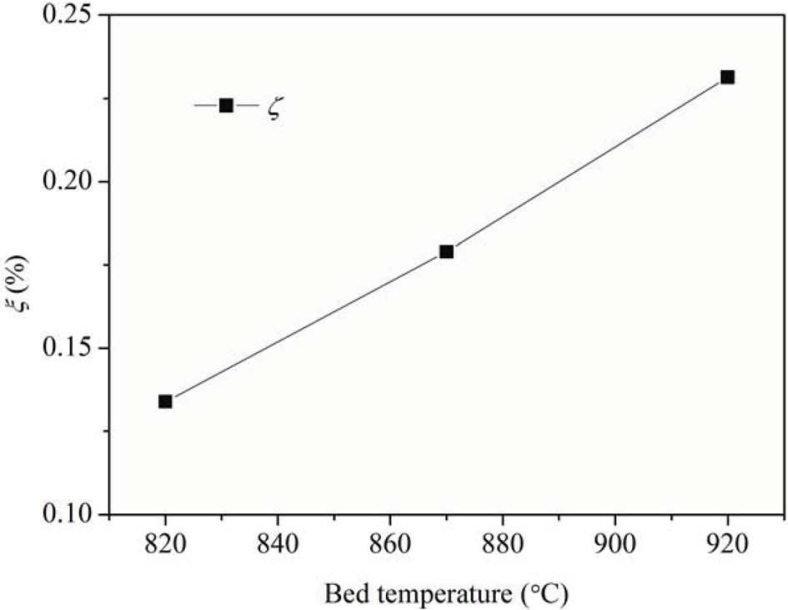

(b) Collection efficiency

Fig. 4 Macro-morphologies of ash deposits and collection efficiency of the slagging probe.

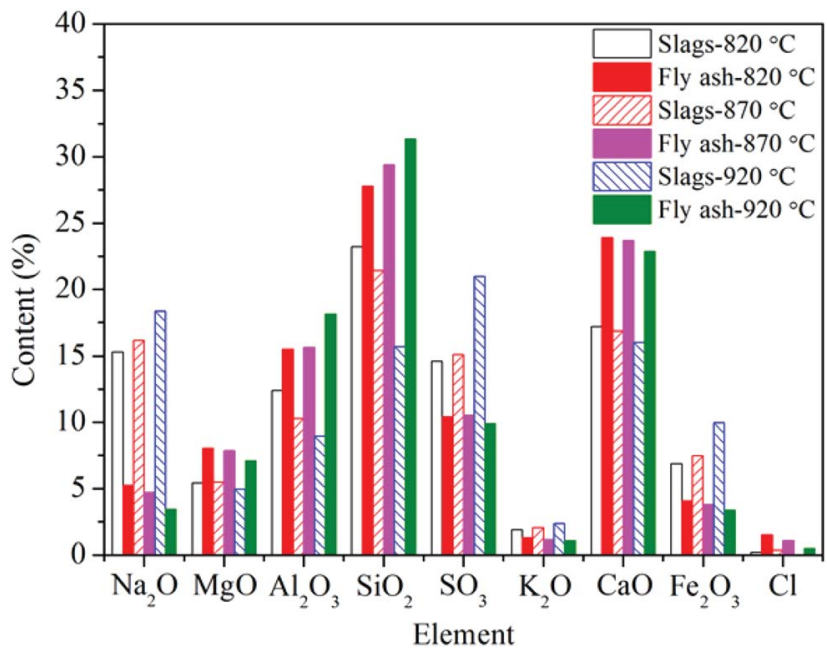

Fig. 5 Chemical compositions of slags and fly ash.

inferred that $\mathrm{Na}, \mathrm{K}, \mathrm{Fe}$, and $\mathrm{S}$, would vaporize into the flue gas during combustion, and subsequently would assume important roles with regard to the slag formation. Compared to $\mathrm{K}, \mathrm{Na}$ is dominant in coal, and its enrichment on the slagging probe is more conspicuous. Correspondingly, the alkali earth metals $(\mathrm{Ca}$ and $\mathrm{Mg}$ ) and acidic elements ( $\mathrm{Si}$ and $\mathrm{Al}$ ) in the slags decrease due to their relatively low volatility, given the specific test conditions.

3.1.3 Mineral compositions of slags and fly ash. The mineral compositions of fly ash are shown in Fig. 6. At bed temperatures in the range of $820-920^{\circ} \mathrm{C}$, the minerals in the fly ash mainly include quartz $\left(\mathrm{SiO}_{2}\right)$, anhydrite $\left(\mathrm{CaSO}_{4}\right)$, hematite $\left(\mathrm{Fe}_{2} \mathrm{O}_{3}\right)$, periclase $(\mathrm{MgO})$, and lime $(\mathrm{CaO})$. Sanidine $\left(\mathrm{K}_{0.42^{-}}\right.$ $\mathrm{Na}_{0.58} \mathrm{Ca}_{0.03}\left(\mathrm{AlSi}_{3} \mathrm{O}_{8}\right)$ exists in the fly ash at a bed temperature of $920^{\circ} \mathrm{C}$, while Na-containing minerals are not detected at $820^{\circ} \mathrm{C}$ and $870{ }^{\circ} \mathrm{C}$. In fact, the content of $\mathrm{Na}_{2} \mathrm{O}$ in fly ash decreases as a function of combustion temperature, as shown in Fig. 5. According to chemical fractionation analysis, $\mathrm{Na}$ in the coal/ash is classified into water $\left(\mathrm{H}_{2} \mathrm{O}\right)$-soluble $\mathrm{Na}($ e.g. $\mathrm{NaCl})$, ammonium acetate $\left(\mathrm{NH}_{4} \mathrm{Ac}\right)$-soluble $\mathrm{Na}$ (e.g. carboxylate), hydrochloric acid ( $\mathrm{HCl}$ )-soluble $\mathrm{Na}$ (e.g. clay), and none-soluble $\mathrm{Na}$ (e.g. aluminosilicate). ${ }^{27}$ The existing forms of Na will change during the combustion process. At low temperatures, $\mathrm{H}_{2} \mathrm{O}$-soluble $\mathrm{Na}$ is the predominant chemical form of total $\mathrm{Na}$ in fly ash. As the

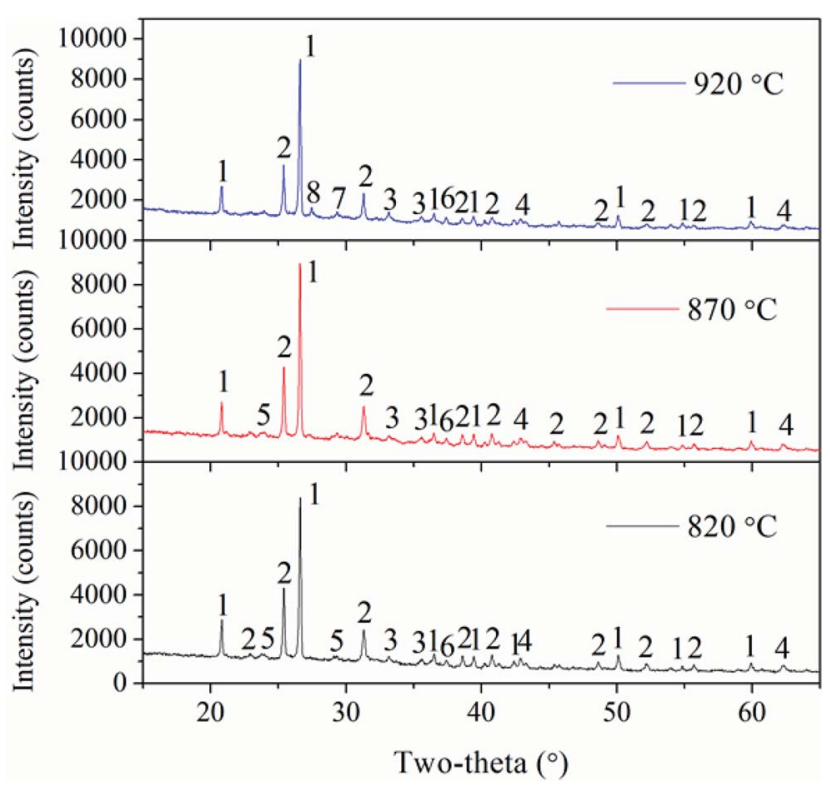

Fig. 6 XRD patterns of fly ash at different bed temperatures. 1-Quartz $\left(\mathrm{SiO}_{2}\right), 2$-anhydrite $\left(\mathrm{CaSO}_{4}\right), 3$-hematite $\left(\mathrm{Fe}_{2} \mathrm{O}_{3}\right), 4$-periclase $(\mathrm{MgO}), 5$ gehlenite $\left(\mathrm{Ca}_{2}\left(\mathrm{Al}(\mathrm{AlSi}) \mathrm{O}_{7}\right)\right)$, 6 -lime $(\mathrm{CaO}), 7$-akermanite $\left(\mathrm{Ca}_{2} \mathrm{Mg}\left(\mathrm{Si}_{2} \mathrm{O}_{7}\right)\right)$, and 8-sanidine $\left(\mathrm{K}_{0.42} \mathrm{Na}_{0.58} \mathrm{Ca}_{0.03}\left(\mathrm{AlSi}_{3} \mathrm{O}_{8}\right)\right)$. 


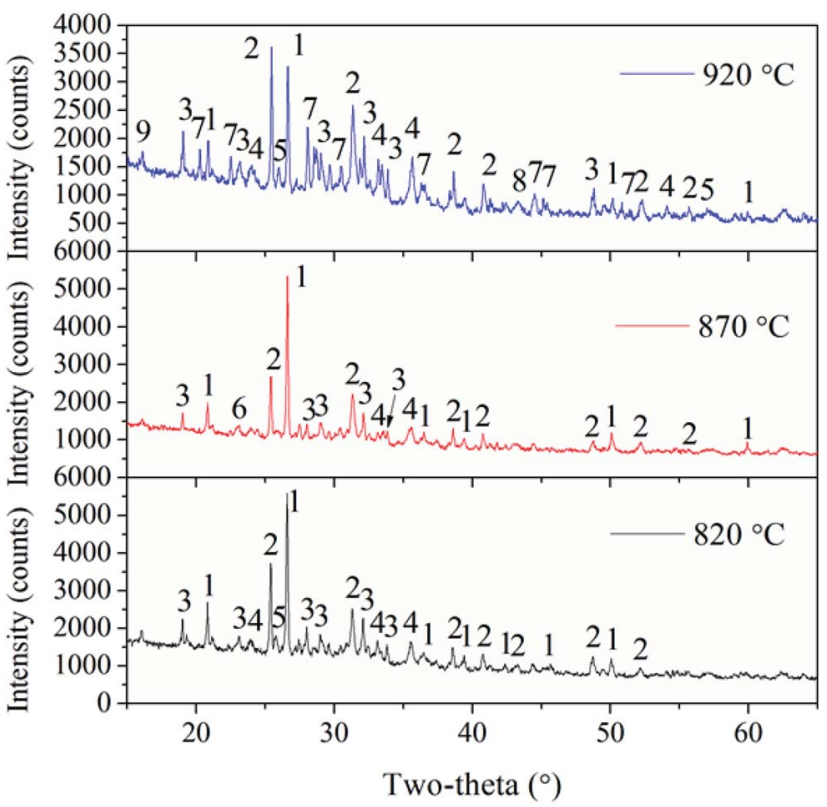

Fig. 7 XRD patterns of slags at different bed temperatures. 1-Quartz $\left(\mathrm{SiO}_{2}\right), 2$-anhydrite $\left(\mathrm{CaSO}_{4}\right), 3$-thenardite $\left(\mathrm{Na}_{2} \mathrm{SO}_{4}\right)$, 4-hematite $\left(\mathrm{Fe}_{2} \mathrm{O}_{3}\right), 5$-fenaksite $\left(\mathrm{KNaFe}\left(\mathrm{Si}_{4} \mathrm{O}_{10}\right)\right)$, 6-nepheline $\left(\mathrm{KNa}_{3}\left(\mathrm{AlSiO}_{4}\right)_{4}\right), 7$ glauberite $\left(\mathrm{CaNa}_{2}\left(\mathrm{SO}_{4}\right)_{2}\right)$, 8-magnesioferrite $\left(\mathrm{MgFe}_{2} \mathrm{O}_{4}\right)$, and 9-andalusite $\left(\mathrm{Al}_{2}\left(\mathrm{SiO}_{4}\right) \mathrm{O}\right)$.

combustion temperature increases, none-soluble $\mathrm{Na}$ increases. ${ }^{12,13}$ Thus, $\mathrm{H}_{2} \mathrm{O}$-soluble $\mathrm{Na}$ in the amorphous phase cannot be detected by the XRD technique. ${ }^{28}$ The non-soluble compound, i.e. sanidine, is only observed at a bed temperature of $920^{\circ} \mathrm{C}$.

In addition, combustion temperatures also have important roles in the transformation of Ca-containing minerals. Gehlenite
$\left(\mathrm{Ca}_{2}\left(\mathrm{Al}(\mathrm{AlSi}) \mathrm{O}_{7}\right)\right)$ exists in fly ash at the bed temperatures of $820{ }^{\circ} \mathrm{C}$ and $870{ }^{\circ} \mathrm{C}$, but it disappears and a new Ca-containing mineral, i.e. akermanite $\left(\mathrm{Ca}_{2} \mathrm{Mg}\left(\mathrm{Si}_{2} \mathrm{O}_{7}\right)\right)$, is observed as the temperature is further increased. The reaction of gehlenite, quartz, and periclase generates akermanite. ${ }^{2}$ These two Caspecies are fluxing materials and can enhance ash deposition. ${ }^{10,29}$

To better understand the slag formation in the furnace, Fig. 7 shows the mineral compositions of slags at different bed temperatures. At the bed temperatures of $820{ }^{\circ} \mathrm{C}$ and $870{ }^{\circ} \mathrm{C}$, there is no obvious difference in the mineral types. Thenardite $\left(\mathrm{Na}_{2} \mathrm{SO}_{4}\right)$ is the main existing form of $\mathrm{Na}$ in the slags. It has been proven that Na vaporized during combustion mainly in the form of oxides, atoms and chlorides. ${ }^{1}$ Additionally, $\mathrm{Na}_{2} \mathrm{SO}_{4}$ is generated from the sulphuration reaction between vaporized $\mathrm{Na}$ species and $\mathrm{SO}_{2}$ in the flue gas. When the flue gas flows across the slagging probe, the gaseous $\mathrm{Na}_{2} \mathrm{SO}_{4}$ in it will condense on the heating surface at relatively low temperatures. This may result in the increase in surface stickiness and thus, the impinging fly particles could be easily captured. Furthermore, part of the condensed $\mathrm{Na}$ and $\mathrm{K}$ species may react with aluminosilicates to form nepheline $\left(\mathrm{KNa}_{3}\left(\mathrm{AlSiO}_{4}\right)_{4}\right)$. As the temperature increases, glauberite $\left(\mathrm{CaNa}_{2}\left(\mathrm{SO}_{4}\right)_{2}\right)$ is generated because of the abundance of $\mathrm{CaSO}_{4}$ in the fly ash. The low-melting compound of $\mathrm{Na}_{2} \mathrm{SO}_{4}{ }^{-}$ $\mathrm{CaSO}_{4}$ will further aggravate the slag formation.

Additionally, Fe partly vaporizes under the reducing atmosphere of char particles and then reacts with oxygen when it diffuses from the char to the ambient environment during coal combustion..$^{30}$ It is enriched in the slags in the form of hematite $\left(\mathrm{Fe}_{2} \mathrm{O}_{3}\right)$. As shown in Fig. 5, the $\mathrm{Fe}_{2} \mathrm{O}_{3}$ content in the slags at $820^{\circ} \mathrm{C}$ is the lowest, and it is only as high as $6.9 \%$. Additionally, $\mathrm{Fe}_{2} \mathrm{O}_{3}$ is a fluxing mineral and the ash particles with mineral concentrations in excess of $5 \% \mathrm{Fe}_{2} \mathrm{O}_{3}$ are easily fused. ${ }^{31}$ Thus, $\mathrm{Fe}_{2} \mathrm{O}_{3}$, together with the low-melting $\mathrm{Na}_{2} \mathrm{SO}_{4}$ and $\mathrm{CaSO}_{4}$ can

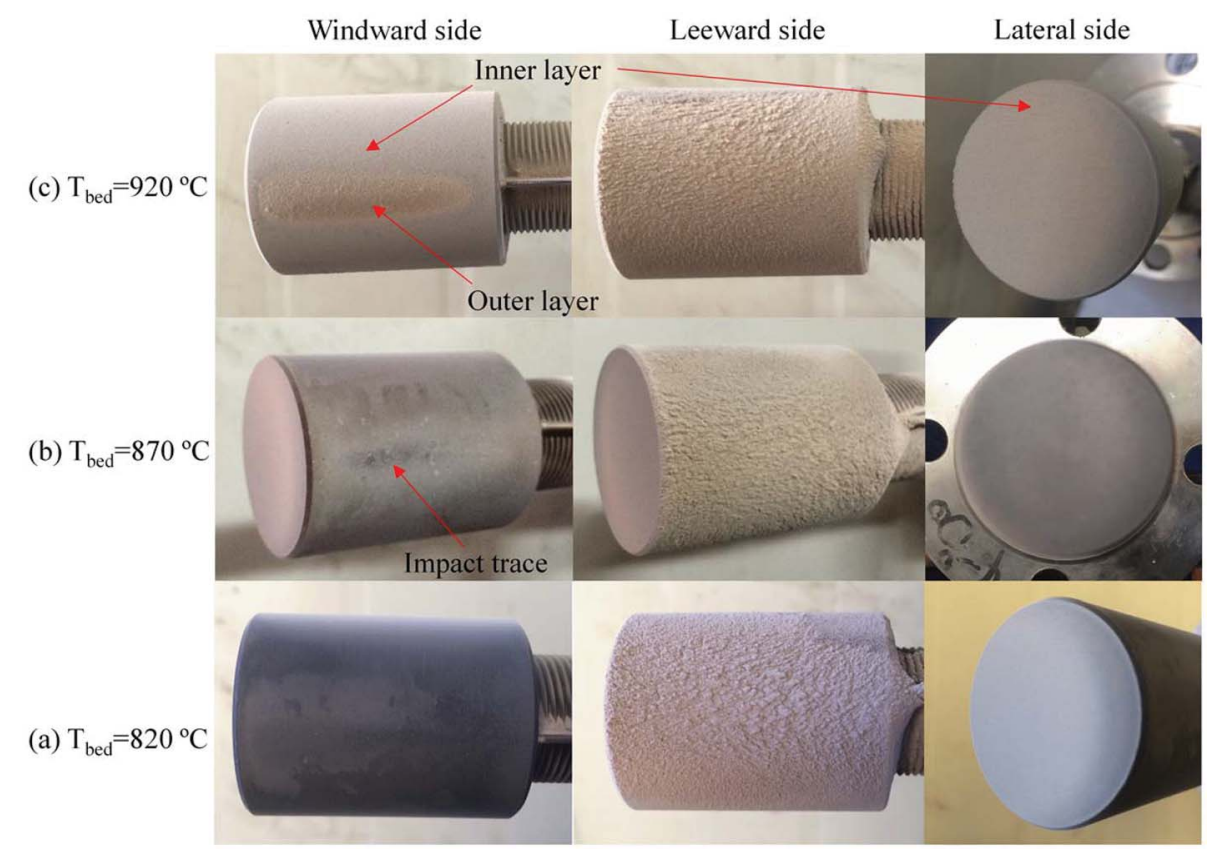

Fig. 8 Macro-morphologies of ash deposits on the ash deposition probe. 


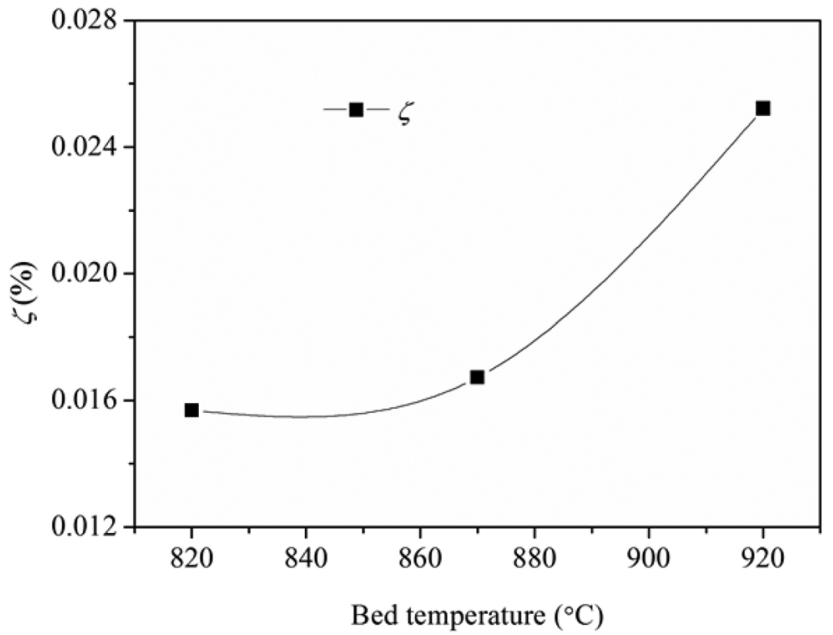

Fig. 9 Collection efficiency of the ash deposition probe.

form $\mathrm{Na}-\mathrm{Fe}-\mathrm{Ca}$ eutectics, which is the main reason for the formation of compacted slags because of their high content. Meanwhile, the reaction between AAEMs and Fe will take place and generate the low-melting minerals such as fenaksite $\left(\mathrm{KNaFe}\left(\mathrm{Si}_{4} \mathrm{O}_{10}\right)\right)$ and magnesioferrite $\left(\mathrm{MgFe}_{2} \mathrm{O}_{4}\right)$.

\subsection{Ash deposition behavior in the convection region}

3.2.1 Morphologies of deposited ash. Fig. 8 shows the macro-morphologies of ash deposits on the ash deposition probe. They are grey-white in color and loose in structure. Their morphologies are significantly affected by the combustion temperature. The layered-structure ash deposits, i.e. the inner and outer layers, are only formed on the windward side at the bed temperature of $920^{\circ} \mathrm{C}$. The inner layer consists of fine particles that are evenly distributed on the entire side. The outer layer, which is cone-shaped ash stacking, is located at the stagnation area. At $870{ }^{\circ} \mathrm{C}$, the number of fine particles decreases. Instead of ash stacking, the impact trace is observed at the same place. This indicates that the impinging ash cannot be captured by the surface. As the bed temperature is further decreased to $820{ }^{\circ} \mathrm{C}$, the surface of the probe becomes clean and minute amounts of ash are deposited. Thus, the inner layer is crucial for the formation of the outer layer. On the leeward side, the deposited ash exists on the entire surface and their morphologies have no obvious difference. Furthermore, the inner layer is also formed on the lateral side parallel to the gas flow. ${ }^{\mathbf{1 0}}$

Fig. 9 shows the collection efficiency of the ash deposition probe. The collection efficiency increases as a function of the bed temperature, especially when the temperature increases from $870{ }^{\circ} \mathrm{C}$ to $920^{\circ} \mathrm{C}$. This is mainly attributed to the formation of deposited ash on the windward side.

Because the macro-morphologies of deposited ash formed at $920{ }^{\circ} \mathrm{C}$ are most representative, their SEM micro-morphologies are further shown in Fig. 10. The inner layer, which is formed both on the windward and lateral sides of the probe, is composed of particles with the size of $<2 \mu \mathrm{m}$. Moreover, they are viscous and aggregate together to form a continuous ash layer. Most deposited particles in the outer layer are larger than 10 $\mu \mathrm{m}$, while those at the leeward are less than $10 \mu \mathrm{m}$. The deposited ash is composed of irregular particles almost in its

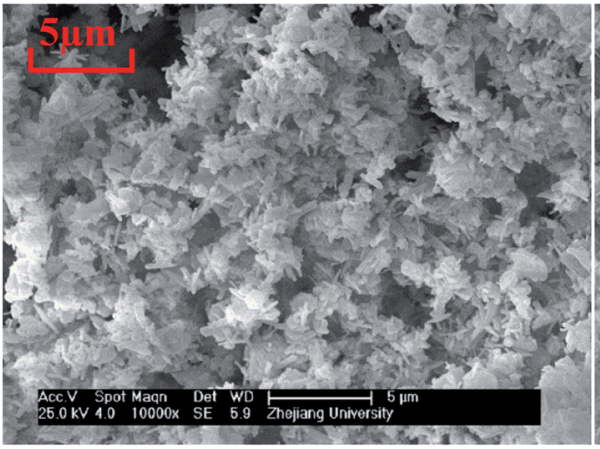

(a) Inner layer-windward side

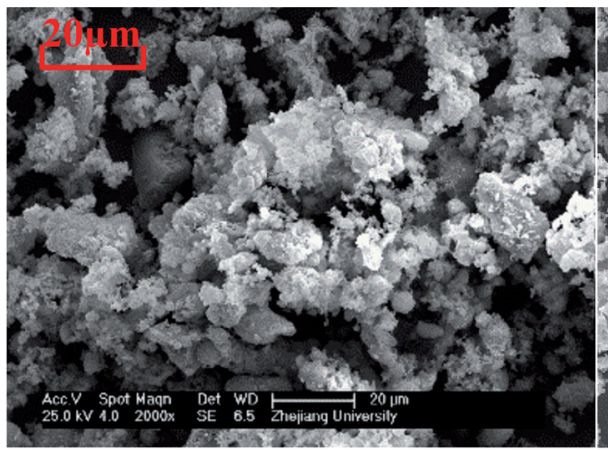

(c) Outer layer-windward side

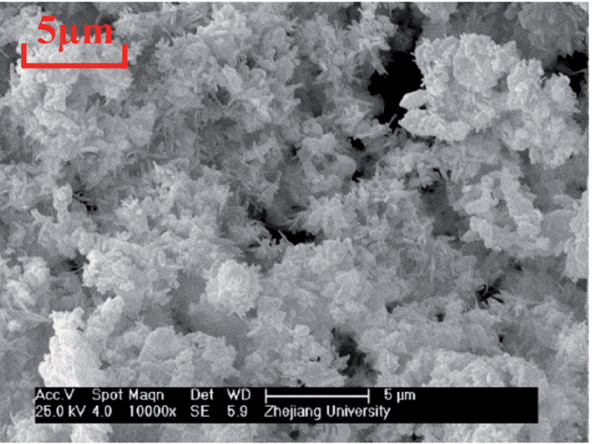

(b) Inner layer-lateral side

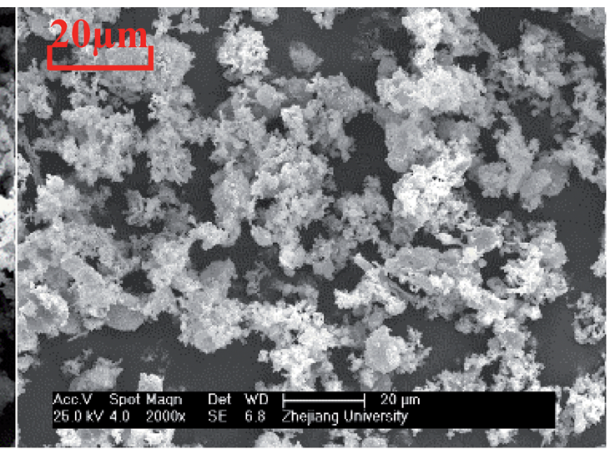

(d) Leeward side

Fig. 10 Micro-morphologies of ash deposits on the ash deposition probe $\left(T_{\text {bed }}=920{ }^{\circ} \mathrm{C}\right)$. 


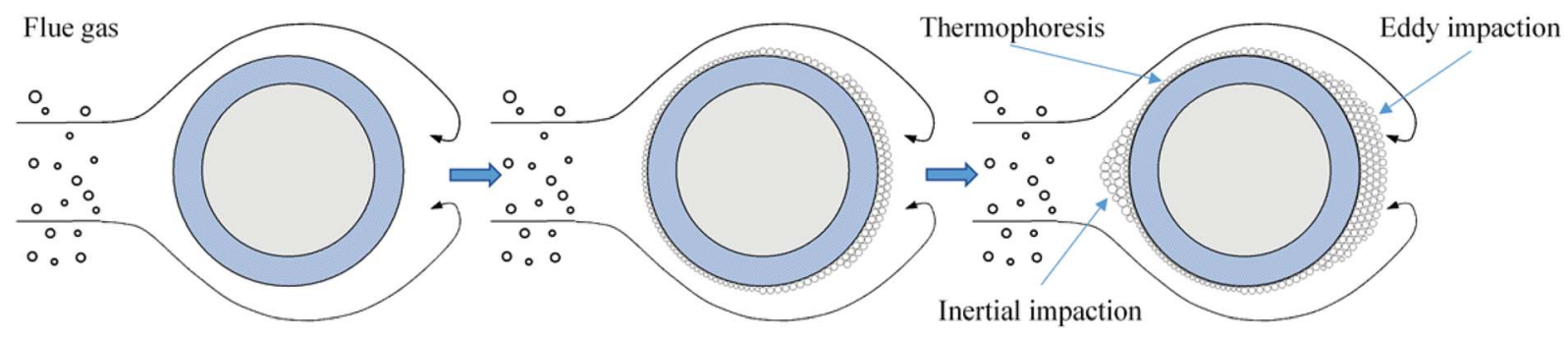

(a) Initial stage

(b) Transition stage

(c) Stable stage

Fig. 11 Schematic showing the stages of the ash deposition formation.

entirety, and only a few spheres are found. This is ascribed to the relatively low-combustion temperature compared to that in pulverized boilers $\left(>1100{ }^{\circ} \mathrm{C}\right)$. The melting phenomenon of fly ash particles does not take place in the CFB system.

In addition to the temperature, the ash deposition formation is also related to the flow field according to the macromorphologies of deposited ash. In the specific test conditions (gas velocity: 8.9-9.9 $\mathrm{m} \mathrm{s}^{-1}$ ), the flow field is a typical turbulent cross-flow field when the flue gas flows across the ash deposition probe. ${ }^{32}$ To better elucidate the ash deposition mechanism, the deposition formation is schematically shown in Fig. 11. At the initial stage, the coarse particles $(>10 \mu \mathrm{m})$ have sufficient inertia to escape from the gas streamlines and subsequently impact on the bare surface of the windward side. However, they are easy to rebound and cannot be deposited due to their considerably huge kinetic energy. ${ }^{33}$ As the test proceeds, the inner layer is formed on the bare surface after the deposition of fine particles $(<2 \mu \mathrm{m})$, which results from the thermophoresis. It can provide the buffering effect for the impinging particles, and their kinetic energy can be effectively dissipated. Therefore, the probability that impinging particles will stick is increased, thus leading to the formation of an outer layer. On the leeward side, turbulent eddy impaction is the controlling mechanism, which also exists in practical boilers. ${ }^{34}$ Only small particles $(<10 \mu \mathrm{m})$ can continue to flow along with the streamlines, due to low inertia, and are then impacted and deposited on the surface.

3.2.2 Chemical compositions of deposited ash. Fig. 12 shows the chemical composition of the deposited ash at a bed temperature of $920{ }^{\circ} \mathrm{C}$. Compared to fly ash, the contents of $\mathrm{Na}_{2} \mathrm{O}, \mathrm{K}_{2} \mathrm{O}$, and $\mathrm{SO}_{3}$ in the inner layer are significantly higher. During coal combustion, fine particles are generated from the condensation and nucleation of gaseous minerals. ${ }^{11,30}$ The gaseous alkali sulfates tend to accumulate in the fine particles as the flue gas temperature is lowered. Moreover, the amount of vaporized alkali metals is positively correlated with the combustion temperature. As the bed temperature is decreased, the amount of fine particles decreases as well. ${ }^{35}$ Consequently, the inner layer is absent at the bed temperature of $820^{\circ} \mathrm{C}$ and $870^{\circ} \mathrm{C}$, which does not cause any deposition of coarse particles.

For the deposited ash on the leeward side, the contents of $\mathrm{Na}_{2} \mathrm{O}, \mathrm{CaO}, \mathrm{MgO}$, and $\mathrm{SO}_{3}$, are higher compared to those in the fly ash. Especially for $\mathrm{Ca}$ and $\mathrm{Mg}$, they play dominant roles on the formation of small particles $(<10 \mu \mathrm{m})$, which are believed to be formed through bulk fragmentation and coalescence. ${ }^{36}$
Additionally, the chemical composition of deposited ash on the outer layer is closest to that of fly ash.

Unlike slags in the furnace, the contents of $\mathrm{Fe}$ in different deposited ash are almost the same as that in fly ash. On the one hand, vaporized Fe can nucleate to form ultrafine particles after combustion. On the other hand, organically bound Fe may experience fusion and coalescence on the burning char surface and contribute to the formation of particles with the size of 1-10 $\mu \mathrm{m} .{ }^{36}$ Wang et al. ${ }^{37}$ carried out combustion experiments to study the effects of coal blending on the reduction of ash particles that were smaller than $10 \mu \mathrm{m}$. It was found that the high content of $\mathrm{Ca}$ can promote the liquid phase substance generated, thus leading to the formation of larger $\mathrm{Ca}-\mathrm{Fe}-\mathrm{Al}-\mathrm{Si}$ or $\mathrm{Fe}-$ Al-Si particles $(>10 \mu \mathrm{m})$. Thus, part of Fe may be transformed from fine particles to coarse particles. It has no significant influence on the formation of ash deposition in the convection region.

\subsection{The effect of kaolin}

3.3.1 Morphologies of ash deposits. Because the ash deposition is most extensive at the bed temperature of $920{ }^{\circ} \mathrm{C}$, the effect of kaolin was evaluated at this temperature. Fig. 13 shows the macro-morphologies of ash deposits after adding kaolin: the compacted ash layer disappears from the slagging

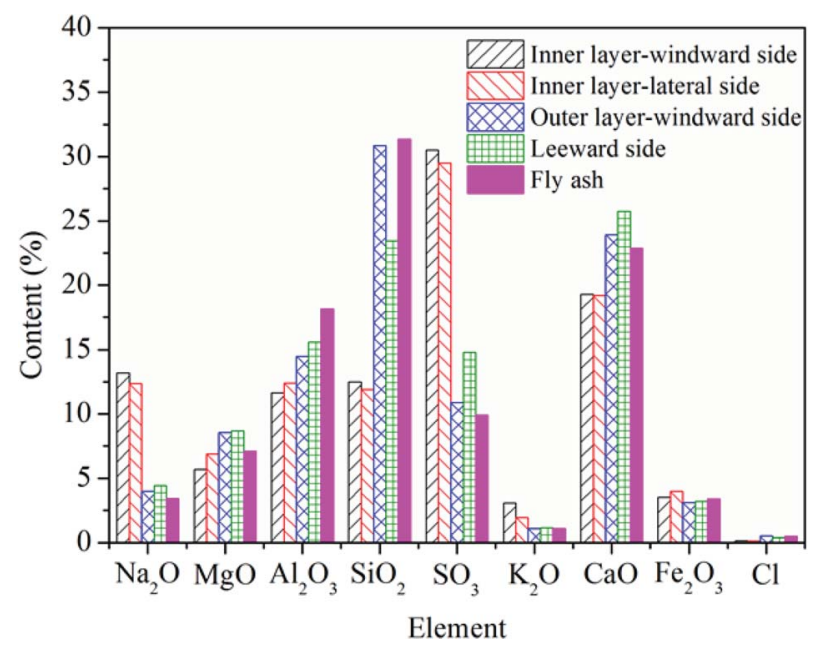

Fig. 12 Chemical compositions of ash deposits and fly ash ( $T_{\text {bed }}=920$ ${ }^{\circ} \mathrm{C}$ ). 
(b) $6 \%$

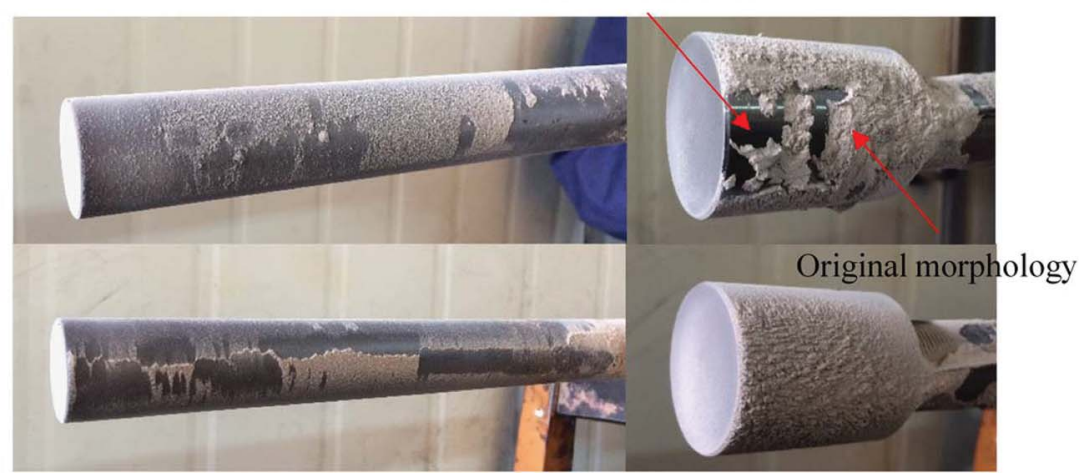

Fig. 13 Macro-morphologies of deposits after the addition of kaolin $\left(T_{\text {bed }}=920^{\circ} \mathrm{C}\right)$.

probe and is replaced by loose and granular particles. They are easy to shed when the probe is moving. On the ash deposition probe, no ash was found on the windward side (not shown in Fig. 13). The deposited ash was mainly located on the leeward side. The adhesion force between the deposited ash and surface was weak; during the collection process, the ash was easily brushed off and the smooth surface quickly appeared (Fig. 13).

According to Fig. 14, the collection efficiency of the ash deposition probe decreases at $3 \%$ kaolin but increases when the kaolin addition ratio reaches $6 \%$. Even so, this is below the value of burning raw coal. This indicates that the deposition tendency can be improved after adding 3\% and 6\% kaolin. Upon the addition of $3 \%$ kaolin, the collection efficiency reached a minimum, which mainly resulted from the disappearance of deposits on the windward side. In the tests, the Sauter mean diameter of kaolin was less than $10 \mu \mathrm{m}$ and the number of small particles in the flue gas increased. Takuwa and Naruse also reported that the fraction of small particles with the size of 1-10 $\mu \mathrm{m}$ significantly increased after the addition of kaolin..$^{38}$ These small particles are prone to deposit on the leeward side. Thus, the collection efficiency again increases as the kaolin is further increased. Wu et al. ${ }^{39}$ studied the ash transformation and deposition in a full-scale wood suspensionfired boiler with and without the addition of coal fly, which was

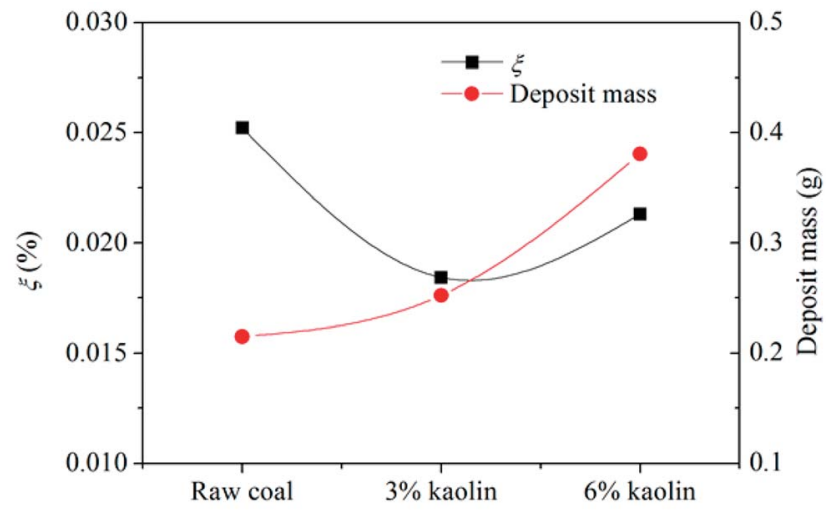

Fig. 14 Collection efficiency of ash deposition and net deposit mass after the addition of kaolin. rich in $\mathrm{Si}$ and Al. It was found that the ash deposition rate was increased after the addition of coal fly ash, which partly resulted from the increase of ash flux.

3.3.2 Mineral compositions of fly ash. Fig. 15 shows the mineral compositions of fly ash after the addition of kaolin. In comparison to the fly ash without kaolin (Fig. 6), some new Nacontaining aluminosilicates, including sodium aluminum silicate $\left(\mathrm{Na}_{6} \mathrm{Al}_{4} \mathrm{Si}_{4} \mathrm{O}_{17}\right)$ and albite $\left(\mathrm{Na}\left(\mathrm{AlSi}_{3} \mathrm{O}_{8}\right)\right)$ were detected. These $\mathrm{Na}$ aluminosilicates were generated by the absorption reactions between kaolin and volatilized $\mathrm{Na}$, thus resulting in a remarkably decreased amount of vaporized $\mathrm{Na}$ in the flue gas. ${ }^{21}$ The compacted slags in the furnace were mainly induced by the condensation of $\mathrm{Na}_{2} \mathrm{SO}_{4}$, while the inner layer on the convection-heating surface was related to fine particles rich in $\mathrm{Na}_{2} \mathrm{SO}_{4}$; therefore, they were effectively suppressed by kaolin. Additionally, mullite $\left(\mathrm{Al}_{6} \mathrm{Si}_{2} \mathrm{O}_{13}\right)$ appeared in the fly ash after the addition of kaolin, possibly generated from the phase transformation reaction during the heating of kaolin. ${ }^{40}$ As a refractory material with a high melting point, mullite constitutes another important reason for the disappearance of compacted slags. ${ }^{41}$

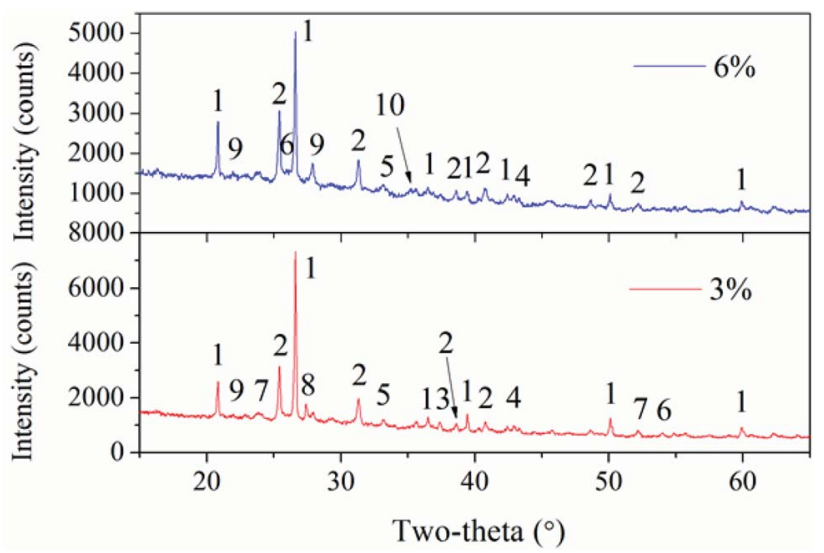

Fig. 15 XRD patterns of fly ash after the addition of kaolin. 1-Quartz $\left(\mathrm{SiO}_{2}\right), 2$-anhydrite $\left(\mathrm{CaSO}_{4}\right), 3$-lime $(\mathrm{CaO}), 4$-periclase $(\mathrm{MgO}), 5$ hematite $\left(\mathrm{Fe}_{2} \mathrm{O}_{3}\right), 6$ - mullite $\left(\mathrm{Al}_{6} \mathrm{Si}_{2} \mathrm{O}_{13}\right)$, 7-gehlenite $\left(\mathrm{Ca}_{2}\left(\mathrm{Al}(\mathrm{AlSi}) \mathrm{O}_{7}\right)\right)$, 8anorthite $\left(\mathrm{Ca}\left(\mathrm{Al}_{2} \mathrm{Si}_{2} \mathrm{O}_{8}\right)\right)$, 9-sodium aluminum silicate $\left(\mathrm{Na}_{6} \mathrm{Al}_{4} \mathrm{Si}_{4} \mathrm{O}_{17}\right)$, and 10 -albite $\left(\mathrm{Na}\left(\mathrm{AlSi}_{3} \mathrm{O}_{8}\right)\right)$. 


\section{Conclusions}

The ash deposition behavior of burning ZD coal with high-alkali metals in a $30 \mathrm{~kW}$ CFB test system was investigated. The fly ash and ash deposits in the furnace and the convection region were collected and analyzed. In addition, the effect of kaolin on the ash deposition was tested with addition ratios of $3 \%$ and $6 \%$. The main conclusions are listed as below:

(1) The slag that formed on the heating surface in the CFB furnace was a compacted ash layer that was difficult to remove. The collection efficiency of the slagging probe increased with the temperature. The melting or partial melting of slags was mainly contributed to the $\mathrm{Na}-\mathrm{Fe}-\mathrm{Ca}$ eutectics. At the bed temperature of $920{ }^{\circ} \mathrm{C}$, the condensed $\mathrm{Na}_{2} \mathrm{SO}_{4}$ reacted with $\mathrm{CaSO}_{4}$ to form the low-melting compound $\mathrm{Na}_{2} \mathrm{SO}_{4}-\mathrm{CaSO}_{4}$.

(2) The deposited ash on a convection-heating surface consisted of granular particles. The layered-structure ash deposits, i.e. the layer and outer layers, on the windward side of the heating surface were only formed at the bed temperature of $920{ }^{\circ} \mathrm{C}$ but not at $870{ }^{\circ} \mathrm{C}$ and $820^{\circ} \mathrm{C}$.

(3) Ash deposition was also related to the flow field around the heating surface. The inner layer was formed by fine particles that were rich in $\mathrm{Na}_{2} \mathrm{SO}_{4}(<2 \mu \mathrm{m})$, due to thermophoresis. The coarse particles $(>10 \mu \mathrm{m})$ were only deposited after the formation of the sticky inner layer, whilst small particles $(<10 \mu \mathrm{m})$ were prone to deposit on the leeward side and were generated from the turbulent eddy impaction.

(4) Slags formed in the furnace appeared as loose ash after the addition of kaolin in the coal because of the absorption of kaolin on alkali metals. The inner layer was effectively suppressed as well. The ash deposition tendency reached its minimum at the addition of $3 \%$ kaolin. Considering the ash content in the flue ash, the net mass of deposited ash increased with the addition of kaolin.

\section{Conflicts of interest}

There is no conflicts to declare.

\section{Acknowledgements}

This work was supported by the Key Project of the National Research Program of China (2015BAA04B02-09).

\section{References}

1 X. Wang, Z. Xu, B. Wei, L. Zhang, H. Tan, T. Yang, H. Mikulčić and N. Duić, Appl. Therm. Eng., 2015, 80, 150159.

2 B. Wei, H. Tan, Y. Wang, X. Wang, T. Yang and R. Ruan, Appl. Therm. Eng., 2017, 119, 449-458.

3 B. Dai, F. Low, A. De Girolamo, X. Wu and L. Zhang, Energy Fuels, 2013, 27, 6198-6211.

4 H. Zhou, B. Zhou, L. Li and H. Zhang, Energy Fuels, 2014, 28, 5756-5765.

5 X. Wu, X. Zhang, K. Yan, N. Chen, J. Zhang, X. Xu, B. Dai, J. Zhang and L. Zhang, Fuel, 2016, 181, 1191-1202.
6 R. W. Bryers, Prog. Energy Combust. Sci., 1996, 22, 20-120.

7 U. Kleinhans, R. Rück, S. Schmid, T. Haselsteiner and

H. Spliethoff, Energy Fuels, 2016, 30, 9793-9800.

8 D. Lindberg, J. Niemi, M. Engblom, P. Yrjas, T. Laurén and M. Hupa, Fuel Process. Technol., 2016, 141, 285-298.

9 U. Kleinhans, C. Wieland, F. J. Frandsen and H. Spliethoff, Prog. Energy Combust. Sci., 2018, 68, 65-168.

10 J. Li, M. Zhu, Z. Zhang, K. Zhang, G. Shen and D. Zhang, Fuel Process. Technol., 2016, 144, 155-163.

11 G. Li, S. Li, Q. Huang and Q. Yao, Fuel, 2015, 143, 430-437.

12 Y. Liu, L. Cheng, Y. Zhao, J. Ji, Q. Wang, Z. Luo and Y. Bai, Fuel Process. Technol., 2018, 169, 288-294.

13 G. Y. Li, C. A. Wang, Y. Yan, X. Jin, Y. H. Liu and D. F. Che, J. Energy Inst., 2015, 89, 48-56.

14 J. Sandberg, C. Karlsson and R. B. Fdhila, Appl. Energy, 2011, 88, 99-110.

15 Z. Gogebakan, Y. Gogebakan, N. Selçuk and E. Selçuk, Bioresour. Technol., 2009, 100, 1033-1036.

16 P. J. van Eyk, A. Kosminski and P. J. Ashman, Energy Fuels, 2012, 26, 118-129.

17 X. Qi, G. Song, W. Song, S. Yang, Z. Yang and Q. Lyu, Energy Fuels, 2017, 31, 13239-13247.

18 G. Song, X. Qi, W. Song and S. Yang, Fuel, 2017, 205, 46-59. 19 S. Kyi and B. L. Chadwick, Fuel, 1999, 78, 845-855.

20 L. Xu, J. Liu, Y. Kang, Y. Miao, W. Ren and T. Wang, Energy Fuels, 2014, 28, 5640-5648.

21 L. Xu, Y. Kang, G. Zhang, T. Wang and T. Wu, Combust. Sci. Technol., 2015, 187, 1959-1973.

22 B. Wei, X. Wang, H. Tan, L. Zhang, Y. Wang and Z. Wang, Fuel, 2016, 181, 1224-1229.

23 Y. Wang, J. Jin, D. Liu, H. Yang and X. Kou, Fuel, 2018, 216, 697-706.

24 E. Rassk, Mineral impurities in coal combustion, Hemisphere Publishing Corporation, Washington, 1985.

25 G. Li, S. Li, X. Xu, Q. Huang and Q. Yao, Energy Fuels, 2014, 28, 219-227.

26 X. Zhang, H. Zhang and Y. Na, Procedia Eng., 2015, 102, 305314.

27 J. Zhang, C. L. Han, Z. Yan, K. L. Liu, Y. Q. Xu, C. D. Sheng and W. P. Pan, Energy Fuels, 2001, 15, 786-793.

28 C. Wang, G. Li, Y. Du, Y. Yan, H. Li and D. Che, J. Energy Inst., 2018, 91, 251-261.

29 G. Kostakis, J. Hazard. Mater., 2011, 185, 1012-1018.

30 R. Ruan, H. Tan, X. Wang, Y. Li, S. Li, Z. Hu, B. Wei and T. Yang, Fuel, 2018, 211, 206-213.

31 W. Xuan, K. J. Whitty, Q. Guan, D. Bi, Z. Zhan and J. Zhang, Energy Fuels, 2015, 29, 405-421.

32 Z. Tong, M. Li, Y. He and H. Tan, Appl. Therm. Eng., 2017, 185, 2181-2193.

33 U. Kleinhans, C. Wieland, S. Babat, G. Scheffknecht and H. Spliethoff, Proc. Combust. Inst., 2017, 36, 2341-2350.

34 L. L. Baxter and R. W. DeSollar, Fuel, 1993, 72, 1411-1418.

35 X. P. Zeng, D. X. Yu, B. Fan, J. Q. Wu and M. H. Xu, J. China Coal Soc., 2015, 40, 2690-2695.

36 X. Gao, M. U. Rahim, X. Chen and H. Wu, Fuel, 2014, 117, 825-832. 
37 Q. Wang, L. Zhang, A. Sato, Y. Ninomiya and T. Yamashita, Fuel, 2008, 87, 2997-3005.

38 T. Takuwa and I. Naruse, Proc. Combust. Inst., 2007, 31, 2863-2870.

39 H. Wu, M. S. Bashir, P. A. Jensen, B. Sander and P. Glarborg, Fuel, 2013, 113, 632-643.
40 C. Y. Chen, G. S. Lan and W. H. Tuan, Ceram. Int., 2000, 26, 715-720.

41 Z. Huang, Y. Li, D. Lu, Z. Zhou, Z. Wang, J. Zhou and K. Cen, Energy Fuels, 2013, 27, 2049-2056. 